\title{
Vizuális kultúra
}

\section{A FIATALOK VIZUÁLIS KULTÚRÁJA - A FINN TANTERV ALAPJA}

\section{YOUTH VISUAL CULTURE PRACTICES AND THEIR RELEVANCE FOR ART EDUCATION IN FINLAND}

\author{
Mira Kallio-Tavin \\ PhD, egyetemi docens, School of Art and Design, Aalto University, Aalto, Finland \\ mira.kallio-tavin@aalto.fi
}

\section{ÖSSZEFOGLALÁS}

\begin{abstract}
A finn vizuális nevelés középpontjában a fiatalok vizuális kultúrája áll, a jelenleg is érvényben lévő, 2014-es finn Nemzeti Alaptantervben a Vizuális nevelés nevű tantárgy első tartalmi egysége ez. A következőkben az általános iskolák új tantervének alapelveit tekintjük át, majd bemutatjuk, hogyan épült be a vizuális nevelés tantervi anyagába a fiatalok saját vizuális kultúrája. Míg az új tanterv még tantárgyakról ír, addig a jövőben elképzelhető, hogy nem tantárgyak köré fog szerveződni az iskola.

A művészeti intézmények egy-egy területre fókuszáltsága, az iskolai tantárgyak izoláltsága helyett egységes, művészetalapú gondolkodás jellemzi az új tantervet. A „mindenütt jelen lévő tanulás" természetének mélyebb megértése alapján folyamatosan változó pedagógiai megoldások születnek a vizuális nevelésben és a múvészetpedagógia más területein is.
\end{abstract}

\section{ABSTRACT}

The visual culture of youth is in the centre of Finnish art education of the National Core Curriculum of Finland issued in 2014, and this is the first thematic unit of the discipline called Visual art education as well. This paper provides an overview of this new curriculum for primary schools and show how the visual culture of youth is integrated in the teaching content. While this curriculum has a disciplinary structure, the Finnish school of the future will presumably not be organised around disciplines at all.

While arts institutions focus on one genre or art form, schools will abandon the isolation of disciplines and manifest a unified, arts-based mentality in the curriculum. A deeper understanding of the "knowledge is present everywhere" leads us to constantly changing, innovative solutions in teaching the visual arts as well as other art forms.

\footnotetext{
${ }^{1}$ Fordította Gaul Emil.
} 
Kulcsszavak: alaptanterv, vizuális kultúra, vizuális nevelés, ifjúsági szubkultúrák

Keywords: core curriculum, visual culture, art education, youth subcultures

\section{AZÚJ FINN ALAPTANTERV}

Az új tantervi reform a fiatalok iskolai tapasztalataiból indult ki (Finnish National Agency for Education, 2014). A központi tanterv a helyi tantervek kialakításához kínál vezérfonalat, és segítséget nyújt a tanulástámogatási programokhoz, a tanulók fejlődésének értékeléséhez és a különleges pedagógiai helyzetek kezeléséhez is. A tantervet megalapozó pedagógiai kutatások fö témája a tanulási hatékonyság javítása mellett a gyermekek boldogsága, iskolai boldogulása volt: vajon hogyan okozhatna több örömet a tanulási folyamat? Másrészt fontos volt elgondolkodni azon is, hogy milyen készségekre és kompetenciákra van szükségük a gyerekeknek és a fiataloknak ma, és milyenekre lesz szükségük a jövőben. Az iskolák működési alapelveit is vizsgálták: az új tantervet meghatározó vizsgálatok témája volt az iskola mint tanulóközösség, amely támogatja a kulturális sokszínúséget, a nyelvi tudatosságot, a jólétet és a részvételt a demokratikus közéletben.

A tanítási-tanulási folyamat jellemző munkamódszere az interakció és a sokoldalúság. Ez a tanterv, amely megőrzi a tantervi kereteket, interdiszciplináris tanulásszervezésre bátorít, és az integrációt az iskolai élet éltetô elemének tekinti. A tantárgyi integráció a jelenségalapú tanulásra² ${ }^{2}$ a tanárok közötti együttmüködésre épül, és a tantárgyi programok összehangolt tervezésére ösztönöz. Az interdiszciplináris tanulást és az integratív módszereket a kereszttanterv, a tantárgyi programok közös témáit és fejlesztési feladatait bemutató dokumentum segít megvalósítani. A keresztkompetenciák a tudás, készségek, értékek, attitüdök és szándékok együtteséből tevődnek össze. A keresztkompetenciák fejlesztése iránt megnövekedett igény a környező világ változásaiból fakad. A műveltségterületi határokon átlépő és a különböző tudásterületeket összekötö kompetenciák a személyes növekedés, tanulás, munka és polgári aktivitás előfeltételei.

A hét keresztkompetencia tartalma:

- A gondolkodás és a tanulás tanulása, amelyben a tanulóknak bemutatják, hogyan rendezhetők új struktúrákba az információk;

\footnotetext{
${ }^{2}$ A tanulás egy jelenség köré szerveződik, hasonlóan a Waldorf-módszer epocháihoz. A jelenségalapú tanulás abból a felismerésből indult ki, hogy a 21. századi élet problémáira nem készít fel kellően a tantárgyakra szabdalt oktatás. A felsőoktatásból ismert módszer először a finn közoktatásban jelent meg rendezőelvként (a ford.).
} 
- Kulturális kompetencia, együttmüködés és önkifejezés, amely segít felismerni a kulturális, nyelvi, vallásos és filozófiai sokszínüséget mint a társadalmi és személyes fejlődés fontos tényezőit;

- Ön-kompetencia: a mindennapi élet megszervezése, hiszen a mindennapi élet egyre több és összetettebb készségeket igényel;

- Többrétegü müveltség (multiliteráció): a tanulók személyiségének fejlesztése értékítéletek megfogalmazása és mások ítéleteinek interpretálása során, a különböző társadalmi helyzetek jobb megértésére és a kultúrák közötti kommunikáció hatékonyabbá tétele érdekében;

- Digitális kompetencia mint a kortárs műveltség része;

- A munka világára felkészitö „,munkaképesség” és a vállalkozói kompetencia, amely a globalizált világban, a technológiai változások közepette végzendő munkára tesz alkalmassá;

- Részvétel a közéletben és fenntartható jövő épitése, amely a tanulókban erősíti a közügyek gyakorlásában való részvétel szándékát és a demokratikus állampolgári létre készít fel.

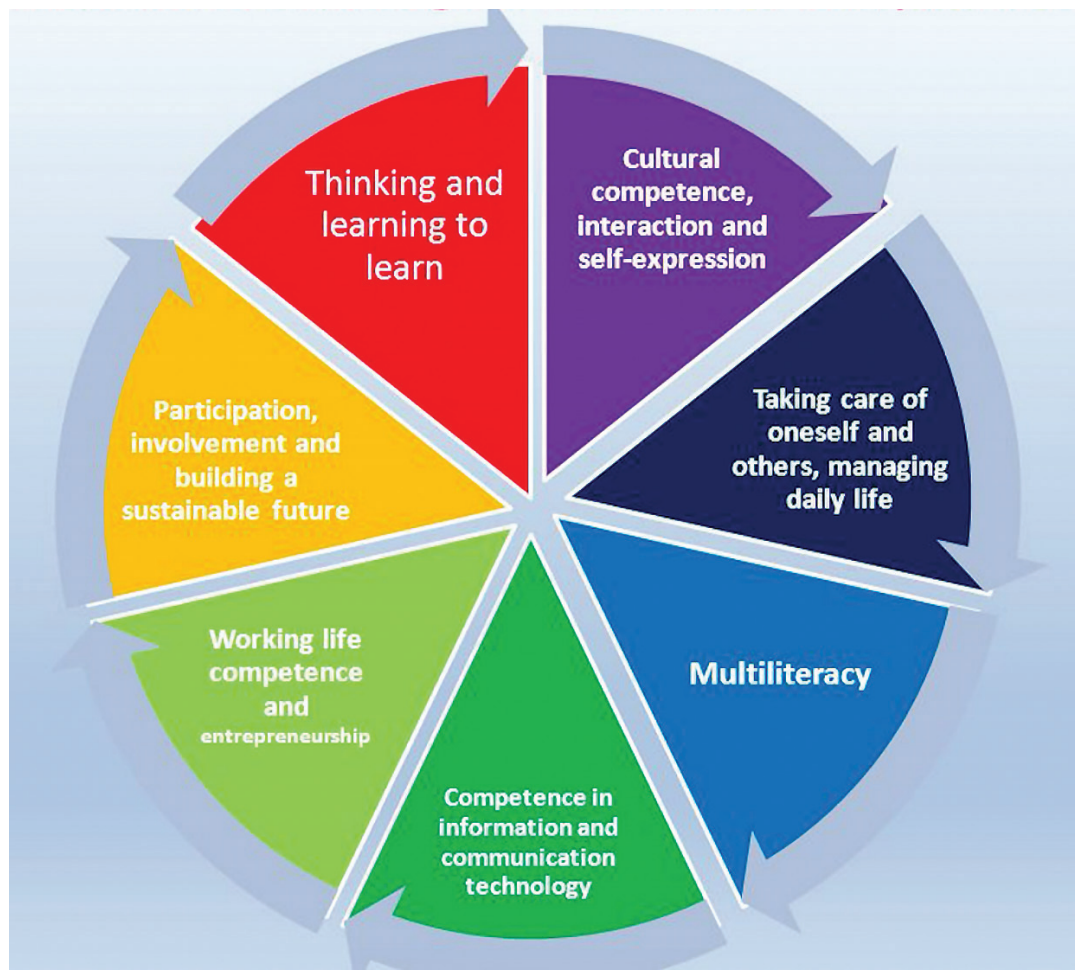

1. ábra. A keresztkompetenciák (Finnish National Agency for Education) (Az ábra szövege megegyezik a fentebbi felsoroláséval.) 
A keresztkompetenciák meghatározásával a tanterv összeköti az iskolai tanulást a mindennapi élettel. A mai és a jövőbeli munkahelyek csapatmunkát és vállalkozói készséget igényelnek. Egyre nő az igény a kreatív, müvészi, design-szemléletű és a képzelőerőre alapozó gondolkodásra. Jelenleg hatalmas szakadék tátong a fiatalok élete (marginalizáció, munkanélküliség), a munka világa és a munkahelyi elvárások között, a tantervnek ezt a szakadékot kell a képességek fejlesztésével áthidalnia. A következőkben a tanterv és a keresztkompetenciák három területére fókuszálunk, amelyeknek minden müvészetpedagógiai programban helyet kell kapniuk: ezek a többrétegủ mủveltség, a jelenségalapú tanulás és a tanulóközpontú tanítás.

\section{MULTILITERÁCIÓ, JELENSÉGALAPÚ TANULÁS ÉS TANULÓKÖZPONTÚ TANÍTÁS}

A többrétegủ müveltség (multiliteráció) kialakítása a teljes tantervet átszövi. Ez a fogalom a multikulturális kommunikáció és az új technológiák, a digitális kultúra elterjedése során vált fontossá. Ez a tantervi cél a kultúrák és a nyelvek különböző megjelenési formáiban és a kommunikációban megfigyelhető változást jeleníti meg. A multiliteráció magában foglalja a tudományok eltérő nyelvhasználatának megismerését és beépítését a megfelelő iskolai tantárgyak oktatásába. A multiliteráció multimodalitást, a környező világ jelenségeinek sokféle érzékszervvel, egyszerre történő befogadását és feldolgozását is jelenti. Vizuális, auditív, mozgásos, haptikus (tapintásos), numerikus, szóbeli, szaglásos és érzelmi kommunikációs kódokat kell megtanítanunk, hiszen a multimodális érzékelés és információfeldolgozás összes dimenziója releváns a művészet tanulásában.

(Az ábra szövege:

- Külsö világosszürke félkör: müvészetek, testnevelés és technikai tantárgyak, vallás és etika, matematika, társadalomtudományok, természettudományok, nyelvek

- Középső sötétszürke félkör: vizuális, akusztikus, kinetikus - haptikus, numerikus, verbális, szaglásalapú, érzelmi

- Belsö fekete félkör: etnicitás, helyszín, társadalmi csoport, nemek, életkor, képességek, nyelvek, világnézet/hiedelmek/vallások

- Felső szirom: a vizuális müvészetek világa

- Bal oldali szirom: a tanulók saját vizuális kultúrája

- Jobb oldali szirom: a környezet vizuális kultúrája

- Középsö fehér kör: VIZUÁLIS NEveLÉs) 


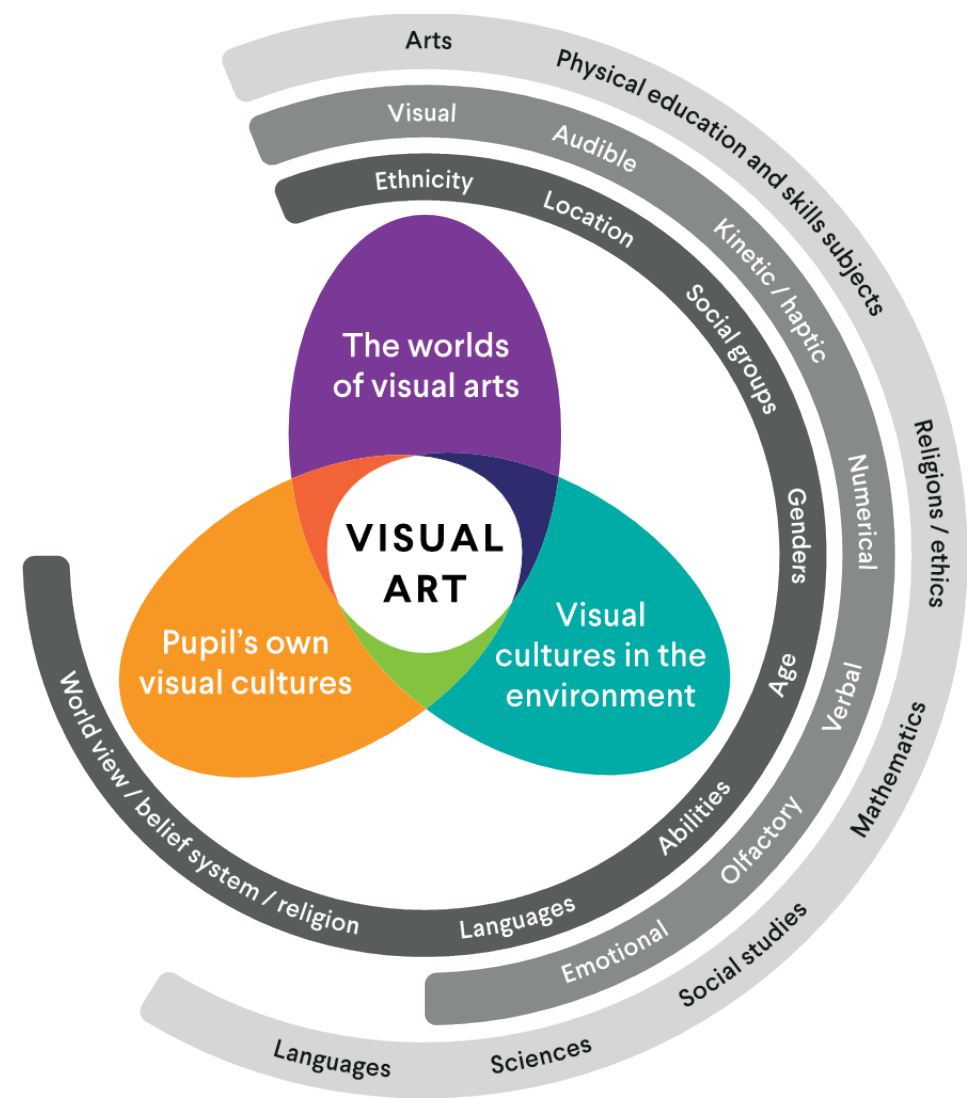

2. ábra. A multiliteráció a vizuális mủvészet tanulása szemszögéből az új finn nemzeti alaptantervben

A jelenségalapú pedagógia a tanulásszervezés egy formája, amely különbözö kutatásalapú pedagógiai módszereket alkalmaz. A jelenségalapú tanulásban a tanítást úgy szervezik meg, hogy a diákok interdiszciplináris szemlélettel értelmezhessék környezetüket. Ennek jegyében a jelenségeket minden oldalról megvizsgálják, majd kontextusba helyezik, hogy a tanulók a tantárgyi határok átlépéséhez alkalmas ismeretet szerezzenek, és készségeket sajátítsanak el. A hangsúly inkább a tanuláson, mint a tanításon van. Ez a fajta munka tanár-diák együttmüködést és tanulóközpontú megközelítést kíván. Olyan pedagógiai helyzeteket kell teremtenünk, amelyekben a tanulók ráébrednek hiányos tudásukra, és késztetést éreznek a hiányok pótlására.

A tanulófókuszú tanulás arra a felismerésre épít, hogy tanulásra mindenütt és bármikor mód nyílhat. A tanulás állandó és mindenütt jelen lévő természete azt jelenti, hogy a tanulás különböző terekben és helyeken történhet meg, a fizikai és 
a virtuális valóságban egyaránt. Az iskola csak egy hely a sok közül, ahol tanulni lehet, talán nem is a legvonzóbb a tanulók, különösen a fiatal gyermekek számára (Kumpulainen et al., 2014). A tanuló szemszögéből nincs különösebb jelentősége annak, hogy a tanulás hol zajlik: az iskolában (ez a formális tanulás) vagy hobbiból, szabadidőben (ez a nonformális, informális tanulás).

\section{TANTERVI VÁLTOZÁSOK A VIZUÁLIS NEVELÉSBEN}

A tanulóközpontú, mindenütt jelen lévő tanulás és a művészetalapú gyakorlat a kortárs finn vizuális müvészeti nevelés alapja. A müvészeti nevelés kereteit kitágító vizuális kultúra műveltségterület a feminista és a kritikai pedagógiából fejlődött ki. Mindkét pedagógiai irányzat az iskolán kívüli tevékenységet hangsúlyozza (Giroux-McLaren, 2001; Hooks, 1994; Tomperi-Piattoeva, 2005). Ebből adódóan az iskola mint intézmény és mint tanulóközösség sem szigetelődik el a világ többi részétől. A kortárs mủvészetpedagógiai felfogás az iskolát és tanárait is tanuló színhelynek, illetve közösségnek tekinti (Senge et al., 2012; Lonka, 2015). Mindent összevetve, a vizuális nevelési tanterv legfontosabb változásai a művészet és a kultúra mélyebb és szélesebb megértéséből adódtak.

A vizuális nevelés tanterve négy fö célt jelöl ki, és ezek a célkitüzések megegyeznek mind a négy korcsoport számára: vizuális megismerés és gondolkodás; vizuális alkotás; a vizuális kultúra közvetítése; esztétikai, ökológiai és erkölcsi értékek. A tanterv a célok kifejtése után, korosztályokra bontott leírásokat is tartalmaz az 1-2., 3-6. és 7-9. évfolyamok számára. A tananyag három témakört ölel fel: a tanulók saját vizuális kultúrája, vizuális kultúra a környezetben, a vizuális müvészetek világa. A tanítók és a rajztanárok ezekre a tartalmi területekre építik fel saját helyi tantervüket.

A Vizuális kultúra a környezetben fejezet az épített és természeti környezet, a használati tárgyak, a média világa és a virtuális valóság megismerését célozza. A környezet vizuális kultúrája az alapja a vizuális munkának. A tanulók a közvetlen és tágabb környezet minőségeit egybevető tanítás és tanulás során vitatják meg a különféle környezeti jelenségek és a média jelentőségét. $A$ vizuális müvészetek világa fejezet a különböző korok, kultúrák, környezetek vizuális művészeti alkotásaiból tartalmaz válogatást. A tanulók a vizuális művészet különféle jelenségeit, koncepcióit a mủvész, a befogadó, az intézmény és a társadalom szempontjából vizsgálják meg. A tanulók saját vizuális kultúrája tantervi egység a tanulók iskolán kívüli vizuális tevékenységére alapul. A tanítás során azt vizsgálják, hogy a tanuló saját vizuális kultúrája hogyan illeszkedik az őt körülvevő környezetbe, és hogyan reflektál a társadalmi helyzetekre, problémákra.

Ez utóbbi, A tanulók saját vizuális kultúrája címü fejezet vált a rajztanterv legvitatottabb részévé. Ez az a rész, amelyik a leginkább különbözik a korábbi 
tantervi előírásoktól. Jóllehet a tanuló feljogosítása arra, hogy saját tanulásának szakértőjeként lépjen fel, már nem új pedagógiai gondolat, néhányan mégis értetlenül fogadták ezt a tantervi részt. Ilyen véleményekkel találkoztunk: „A tanulók saját vizuális kultúrája bevezetése azt jelenti, hogy a vizuális nevelési tanterv egyharmada semmiféle új ismeretet sem tartalmaz, hiszen középpontjában a tanulók saját vizuális kultúráról szerzett tapasztalata kell hogy az előírás középpontjában álljon!” Az új rajztanterv üzenete egyáltalán nem ez.

A gyermekek és a fiatalok termékeny vizuális alkotók, és gazdag képi választékból fogyasztanak, mégsem mondható el róluk, hogy a vizuális müveltség szakértőjeként jönnének a világra. Ha a tanulók tapasztalataiból indulunk ki, akkor váratlan helyzetekkel kerülhetünk szembe: olyan helyzetekkel, amelyeket nehéz előre megjósolni és eltervezni. Ez bizony bátorságot igényel a tanártól (Hyvärinen-Särkelä, 2015). Az elszántság mellett a másik fontos követelmény, hogy felismerjük: a tanulók vizuális kulturális tevékenysége nem mindig képi jellegü, hanem különböző médiumokban létrejövő én-kifejezéseket is tartalmazhat. Hogy ezeket megértsük és elfogadjuk, ahhoz az kell, hogy benne éljünk a kortárs, vizualizált kultúrában.

Az ifjúsági szubkultúrák több alfaja vált vizuálissá annak ellenére, hogy kezdetben nem voltak azok. Ilyen például a gördeszka, a snow board és a parcour (városi terepfutás). Ezek a sportok mára erős képi megjelenítéssel bírnak, a vizuális jelzések önazonosságuk részei (Tani-Ameel, 2015). Például a terepfutó kultúrának elválaszthatatlan része a hirdetésekben, videójátékokban, zenei klipekben és filmekben megjelenő képi reprezentáció. Sok terepfutó maga készíti el a saját klipjét és a sporthoz kötődő egyéb képi jeleit. A filmeket és videókat az interneten osztják meg, és lelkesen kommentelik egymás videóit. Úgy tủnik, hogy nem lehet elválasztani a városi terepfutás kialakult gyakorlatát annak a vizuális megjelenítésétől és mások képeinek fogyasztásától, hiszen ez a képkészítő, képolvasó tevékenység szorosan kötődik magához a sporthoz. A városi terepfutás és annak vizuális megjelenítése közötti szétválaszthatatlan kapcsolat felvet egy kérdést: melyik rész a tevékenység és melyik a reprezentáció? Mivel mindkettő, a tevékenység és a reprezentáció egyaránt fontos, a valódi probléma inkább az, hogyan lehet a tanulók saját kulturális tevékenységét bevonni a vizuális müvészeti tanulásába.

A tanulók saját vizuális kultúrája fejezet sokféle vizuális tevékenységet tartalmazhat: hagyományos vizuális mủvészeti formákat és új müfajokat is. A tanárnak fel kell készülnie, hogy a vizuális kultúra területei közül a számára kevésbé ismerteket is pedagógiai programjába illessze. A diákok tehát bizonyos vizuális tevékenységek szakértőinek tekinthetők. Ez a tantervi terület lehetőséget kínál a tanárnak arra, hogy a diákokkal együtt olyan területeket ismerjen meg, amelyekkel egyébként aligha találkozott volna. A tanítás kulturálisan relevánssá, érdekessé tétele válhat a tanár egyik legfontosabb kompetenciájává. 


\section{ÖSSZEGZÉS}

Megállapítható, hogy a 2014-es finn Nemzeti Alaptanterv a jelenségalapú tanulást, a tantárgyi integrációt, a multiliterációt, értékközvetítést, kulturális sokszínűséget, végül az erkölcsi, esztétikai és ökológiai igazságot hangsúlyozza. A vizuális nevelés integrálása más iskolai tantárgyakkal lehetőséget teremt a tanulóknak arra, hogy a müvészetalapú tanulás módszerével más témakörökről is tanuljanak. Ha a vizuális kultúra elsajátítását kiterjesztjük a tanterv egészére, akkor a vizuális müvészetre úgy tekinthetünk mint tudásszerzési formára, mely a képi kommunikáció kompetenciáját fejleszti. A képértelmezés és képalkotás ma már alapvetően fontos ahhoz, hogy környezetünket képesek legyünk befogadni és értelmezni.

Fontos leszögezni, hogy a tanterv egészére kiterjedő integrált vizuális kompetenciafejlesztés nem szünteti meg az önálló művészeti és környezetkultúra tantárgy és tanterv szükségességét. A vizuális és környezetkultúra tanítását folytatni kell az első osztálytól az érettségiig. A közoktatásban szaktanároknak kell elsajátíttatni a tanulókkal a vizuális müvészetek és tárgykultúra alapjait.

A pedagógusoknak figyelni kell arra, hogy a tanulók mai képalkotó gyakorlata nem szükségszerüen a képi világból táplálkozik. Sok ifjúsági szubkultúra vált alapvetöen vizuális jelenséggé. Vizualitásban gazdag korunkban élve, amikor tanulófókuszú müvészeti tantervünket készítjük, figyelembe kell vennünk, hogy a fiatalok képi kultúrájának számtalan területén a szubkulturális tevékenység és a vizuális megjelenés elválaszthatatlan kapcsolatban áll egymással.

\section{IRODALOM}

Finnish National Agency for Education (2014): http://www.oph.fi/english/curricula_and_qualifications/basic education

Giroux, H. - McLaren, P. (2001): Kriittinen Pedagogiikka. Tampere: Vastapaino

Hooks, B. (1994): Teaching to Transgress: Education as the Practice of Freedom. New York: Routledge

Hyvärinen, R. - Särkelä, E. (2015): Kuvassa kokemus ja paikka - valokuvaamalla nuorten elämismaailma osaksi opetusta. In: Mustola, M. - Mykkänen, J. - Böök, M. L. - Kärjä, A-V. (eds.): Visuaaliset menetelmät lapsuuden- ja nuorisotutkimuksessa. Helsinki: Nuorisotutkimusseura, 159-168.

Kumpulainen, K. - Lipponen, L. - Hilppö, J. - Mikkola, A. (2014): Building on the Positive in Children's Lives: A Co-Participatory Study on the Social Construction of Children's Sense of Agency. Early Child Development and Care, 184, 2, 211-229.

Lonka, K. (2015): Oivaltava oppiminen. Helsinki: Otava

Senge, P. - Cambron-McCabe, M. - Lucas, T. et al. (2012): Schools That Learn. A Fifth Discipline Fieldbook for Educators, Parents, and Everyone Who Cares about Education. New York: Grown Publishing Group 
Tani, S. - Ameel, L. (2015): Nuoret visuaalisten aineistojen tuottajina ja kuluttajina - esimerkkinä parkour. In: Mustola, M. - Mykkänen, J. - Böök, M. L. - Kärjä, A-V. (eds.): Visuaaliset menetelmät lapsuuden- ja nuorisotutkimuksessa. Helsinki: Nuorisotutkimusseura, 149-158.

Tomperi, T. - Piattoeva, N. (2005): Demokraattisten juurten kasvattaminen. In: T. Kiilakoski, T. Tomperi \& M. Vuorikoski (eds.): Kenen kasvatus. Kriittinen pedagogiikka ja toisinkasvatuksen mahdollisuus. Tampere: Vastapaino, 247-286. http://www.uta.fi/edu/opiskelu/opiskelijaksi/ valintakoeaineisto_2011/TomperiPiattoeva.pdf 